\title{
PRACTICAL PROBLEMS IN THE ENFORCEMENT OF ALIMONY DECREES
}

\author{
EDWARd PORORNY*
}

In one form or another the word "alimony," insofar as its import is considered by some lawyers and laymen, contains the sinister idea that it relates solely to the support of worthy and unworthy ex-wives. The common-law definition given by law writers of the term "alimony" is perhaps not broad enough to include provision for infant children of the parties to a divorce. Yet the authors state that some of the statutes and decisions give a broader meaning to the term.

It has been held in Michigan that when the legislature passed the alimony statute it intended to provide a sum to be paid to the wife by the husband for the support of the wife and such children as should be placed in her custody and that this sum, which the statute contemplates is to be paid to her from his estate for her own or children's support, or both, is called "alimony" in the statute and must be treated as such. ${ }^{1}$

In the State of Michigan, the Wayne County Circuit Court, having jurisdiction in divorce matters, recognized the fact that its alimony decrees were not being very regularly complied with, resulting in distress to the dependents and often compelling them to go on public relief. This court was instrumental in presenting a bill to the legislature creating the office of "Friend of the Court" whose duties, defined by the statute, ${ }^{2}$ are to examine records and files in divorce cases where decrees have been rendered for the support of dependent minor children and to bring into court when necessary by citation or otherwise all persons who are delinquent in making such payments. In the County of Wayne, Michigan, with a population of close to 2,000,000 the average monthly divorce decree rate for the past nine years-1930 to $193^{8}$, including depression years when the divorce rate went down all over the country - was $4 \mathrm{r5}$. In close to $4^{\circ}$ per cent of these cases the decrees order support for minor children, and in approximately 3 per cent, for childless wives.

- LL.B., I905, Detroit College of Law. Member of the Michigan Bar. Friend of the Court for the Circuit Court for the County of Wayne, State of Michigan, since 19r8. Attorney for the Legal Aid Bureau of the Detroit Bar Association, I909-rgrg. Member of the Board of Directors of the Children's Aid Society.

${ }^{1}$ Brown v. Brown, 135 Mich. I4I, 97 N. W. 396 (1903); Kutchai v. Kutchai, 233 Mich. 569, 207 N. W. 818 (r926); West v. West, 241 Mich. 679, 217 N. W. 924 (1928).

${ }^{2}$ MrCH. CoMp. Laws (1929) \$12783. 
The office ${ }^{3}$ deals with thousands of men who, having solemnly sworn, when pronouncing their marriage vows, to take their spouses for better or for worse and then having discovered it was all for the worse, suffer some kind of mental reaction in relation to their family responsibilities which makes them fugitives from justice. They become chronic alimony delinquents and rather than be continuously harassed either by their ex-wives or the law, leave the state of their domicil thinking they are forever free from their moral and legal obligations. Such persons may be extradited by virtue of the Michigan statute which makes it a felony to leave the state and fail to support a minor child or children under i7 years of age. ${ }^{4}$

To expedite the hearing in this type of alimony prosecution a criminal warrant is applied for, and, when the defendant is returned to the state awaiting a hearing in the criminal case, he is taken to the circuit court on a writ of attachment and hearing had immediately. ${ }^{5}$ This eliminates the time which would otherwise be taken in appearing before the magistrate and being bound over for trial in the criminal court.

In many cases after the entry of the divorce decree the social status of one or both of the parties changes. The ex-husband is steadily employed, pays his alimony for the support of the children regularly, visits them in accordance with the privileges granted to him in the decree. He begins to tire of a life of solitude or celibacy. He decides to remarry. This act embraces many unforeseen happenings. The ex-wife either becomes jealous or doesn't like the new wife who usually accompanies her

\footnotetext{
${ }^{3}$ The organization of the Friend of the Court consists of the executive, eight assistants, sixteen investigators, two deputy sheriffs, a cashier's department of seven, ten stenographers, a docket clerk, a messenger clerk, a telephone operator, and an information clerk.

The Rules of the Circuit Court of Wayne County define the procedure in divorce, separate maintenance, or marriage annulment cases with reference to this office. All praecipes giving notice of motions in such cases must be filed with the Friend of the Court who is appointed Deputy County Clerk for that purpose, and all motions must be referred to him for investigation and recommendation before being passed on by the court. Objections to the Friend of the Court's recommendations must be served upon his office and upon counsel for the opposite party at least one day before hearing. The Friend of the Court is responsible for the enforcement of all preliminary and interlocutory orders as well as final decrees in such cases. Rule 7.

All payments of alimony whether temporary or permanent, must be paid to the Friend of the Court. Rule 9(a). In all divorce cases where the wife is served either by publication or by registered mail, the decree must expressly reserve the question of alimony for disposition in the event the wife applies therefor in the future. Rule $9(\mathrm{~b})$. The latter rule protects the wife who has had no actual notice of the divorce proceedings.

In cvery case where no answer is filed, the Friend of the Court is required to examine the file and pleadings and to file a written report showing any defects that may appear in the pleadings, serving a copy of his report on the attorney for the plaintiff or the cross-plaintiff. Moreover, no such case shall be assigned for trial until the Friend of the Court has certified to the Assignment Clerk that no jurisdictional defects exist in the pleadings, noting any amendable defects that may still exist therein. Rule 6(a).

The file and pleadings in such cases, together with the report of the Friend of the Court, must be filed with the County Clerk at least four days before the day set for hearing. If the opposite party has appeared by counsel, four days' notice of the hearing must be given to counsel. Where, however, there is one or more children under 17 years of age, or where the wife seeks alimony for herself or maintenance for the children, notice must be given to the Friend of the Court by the party seeking the relief at least three weeks before the final hearing. The case may not be heard until the Fisend of the Court has filed a final report including any recommendations made by him as to alimony and maintenance for children, stating the specific amount, if any, recommended by him. Rule 6(b).

For a more detailed description of the office of the Friend of the Court, see Mrchigan Judicial Councin, Firth ANn. Rep. (Aug., I935) 61 $f$.

E Riegler v. Kalamazoo Circuit Judge, 222 Mich. 421, I92 N. W. 690 (1923).
} 
husband when he visits the children and, if the children are taken to the father's home, the mother's imaginings are limitless. The ex-wife, letting her evil thoughts dominate her, begins a course of conduct which materially affects the rights and privileges granted to the husband in the decree. His reaction reaches the point where he decides that if his ex-wife refuses to comply with the terms of the decree, he will do likewise, and refuses to support the children. This is one of many practical problems in the enforcement of alimony decrees. An experienced officer from the Friend of the Court's office interviews the parties, ascertains the cause of the difficulties and attempts to adjust them. The officer, in the interest of peace and harmony, may deem it necessary to be present at the home of the ex-wife when the ex-husband calls to visit the children or temporarily take them away. The parties' knowledge that an unbiased officer of the court stands ready to investigate complaints, ascertain the facts, and if necessary, initiate contempt proceedings acts as a deterrent to those who are prone to disregard others' rights and the orders of the court.

It is not an uncommon situation for the ex-wife to remarry and should the new husband be of a sensitive disposition and possessed of a strain of jealousy, the step will usually lead to misunderstanding and defiance when the first husband and father of the children calls at the home to visit them. Even though the ex-wife may have no contact with and may not even converse with her former husband, nevertheless the new status creates an atmosphere of unfriendliness which frequently develops into a very hostile attitude. Under these circumstances, only the slightest provocation is needed to call forth remarks of a very offensive nature. Frequently the next step is a declaration by the new husband that the father of the children cannot call at his home to visit them and the father will then retaliate by declaring he will not support them. Such a situation requires tact upon the part of the court officer in bringing the parties to a better understanding. Should our efforts fail, the case goes to court, usually on an order to show cause on the part of the wife against the husband for failing to support the children, and an order to show cause by the husband charging his wife with violating the provisions of the decree relative to either visitation or temporary custody of the children. If the parties are still belligerent when they appear in court and refuse to respect and obey the terms of the decree, a threatened jail sentence usually restores them to a more normal frame of mind.

As I have stated heretofore, the social status of a divorced couple frequently changes after decree. We have had cases where the wife, having remarried, contemplates changing her residence to that of another state and proposes to take her minor child with her. The ex-husband, being domiciled in the state granting the decree, strongly objects to the change of residence of his child whom he is supporting. He contends that the court has granted him visitorial and custody privileges and that removal from the state will destroy contact between father and minor child. Under these circumstances, where the mother unquestionably is a fit and suitable person, it is extremely difficult to take the position that she shall not remove the child out of the jurisdiction of the court. In order to legalize the contemplated change, the ex- 
wife files a petition for modification of the decree praying for an order permitting her to change the child's residence. The court has established the practice that where the mother is of good moral character and has a suitable home for her child, she will be given its custody. If reasonable provisions can be made for the temporary custody of the child during school vacations and holiday periods, an order entered in the lower court approving them will not be disturbed on appeal. ${ }^{6}$ In the event that the mother living in a sister state should refuse to comply with the Michigan decree of divorce, the husband's remedy would be by petitioning a court of the mother's domicil for a writ of habeas corpus for a determination of the respective rights of the parents.

In thousands of cases handled in our department we have recognized a group of alimony recipients who are the beneficiaries of an order for the support of the mother and child or children and are wholly dependent for their sustenance upon payments made thereunder. Under the order of the court the alimony is payable to our department. This practice enables us to determine definitely whether a delinquency exists. Human nature has its weaknesses and these, it seems, frequently affect alimony payers, causing them intermittently to miss weekly alimony payments. This delinquency creates a serious economic upset in the routine life of the mother and children and a complaint is promptly made. One of two things must be done immediatelyobtain an emergency relief order from the welfare department or dispatch an investigator to the place of employment or home of the alimony payer. If no money is obtained from him, an emergency order is requested and if the delinquency is not made up on his next pay day, he is cited to appear in court on a contempt charge.

One of the most disturbing problems in the enforcement of alimony decrees arises in the cases where the husband remarries and produces a second set of children. Being a common workman, receiving ordinary wages, he finds it impossible to contribute to the support of the children of the first marriage. It is difficult by argument or reasoning to change his mental attitude of utter lack of capacity to support the first children. From an economic point of view, he may be right. However, the legal responsibilities fixed in a divorce decree cannot be disregarded. The law must be upheld. This type of case is not easily solved, notwithstanding the father's claim of sincerity and his promise of future support when he is threatened with prosecution. We had a case where one child was born of the first marriage and four of the second marriage. For years the father refused to support his first child. We were unusually lenient and generous towards him in trying to get him to change his attitude. When all efforts failed, one course remained-prosecution for contempt of court. He defended on the ground of total incapacity because of new family obligations. The lower court held that in this situation the child of the first marriage had a priority over the second group, largely for the reason that the father's obligations were adjudicated when the decree was entered and any marital contractual relation entered into by the father thereafter became subject to the rights of the first child. The lower

\footnotetext{
'Epstein v. Epstein, 234 Mich. 200, 207 N. W. 894 (1926).
} 
court was extremely lenient with the respondent and committed him to jail for a period of six months, to be released upon the payment of fifty dollars. His attorney filed a petition in the Supreme Court for a writ of habeas corpus and certiorari. The Supreme Court held that the action of the lower court was justified by the record and dismissed the petition.?

There are many decrees of divorce entered where the children are of tender age. Weekly payments for the support of the minor children is ordered, based upon the financial capacity of the father. These alimony decrees ordinarily run until the children become emancipated or self-supporting. It is to be expected that economic conditions will interfere with the father's capacity to contribute towards the support of his children, by reduction of wages, part-time employment or lay-offs. When the fact of such an interruption in his income is established, the father obviously is without capacity to contribute and if the dependents are without means, welfare relief must be applied for. To prevent any injustice to the father, the divorce decree should be modified to meet the new situation. This course frequently is delayed for financial reasons. So long as the decree remains unmodified, the alimony continues to accumulate and in time reaches a sum wholly beyond the capacity of the father to pay. The accumulation is a factor that can be very troublesome to the father because it encourages unwarranted action upon the part of an unfriendly ex-wife. There are occasions when alimony has accrued to a sum exceeding one thousand or two thousand dollars and, upon application for modification, the ex-husband usually prays for an order cancelling the accumulation. Upon investigation we attempt to obtain accurate information as to the period of unemployment, part-time employment, and reduced wage income. In our state the court has authority to readjust alimony payments retrospectively and determine the amount the ex-husband should or should not pay with respect to the periods when he was without capacity. ${ }^{8}$

The solution of some of the problems involving enforcement of alimony decrees are comparable to a hairline decision made by a baseball umpire-he calls the play as he sees it. For example, a decree of divorce was entered in a certain cause where no minor children were involved. The husband was ordered to pay $\$ 50.00$ per month permanent alimony for the support of his wife. The wife previously had been married and had an adult son who married and had one child. The son did not get along with his wife and a decree of divorce was entered in his case ordering him to pay $\$ 50.00$ a month for the support of his minor child. Thereafter, his stepfather married his ex-wife. The son and his mother moved to another state where he obtained employment and is supporting his mother but is not supporting his own child. His stepfather is supporting his child. The childless ex-wife complained that her ex-husband was not paying $\$ 50.00$ a month for her support. The ex-husband countered with the claim that he is supporting his former wife's grandchild to the extent of $\$ 50.00$ a month and that one set of circumstances should offset the other. I ask the

\footnotetext{
${ }^{T}$ Lupu v. Deniston, 285 Mich. 500, 28x N. W. 236 (I938).

${ }^{8}$ Loomis v. Loomis, 273 Mich. 7, 262 N. W. 331 (x935).
} 
question-what would the reader do under these circumstances with respect to enforcing the alimony provisions of the two decrees?

We made a partial study of 189 contempt cases presented to the court for nonpayment of alimony. In 160 cases there were minor children and in 29 cases, no children of the marriage. The following table shows the number of prosecutions for non-compliance of alimony orders:

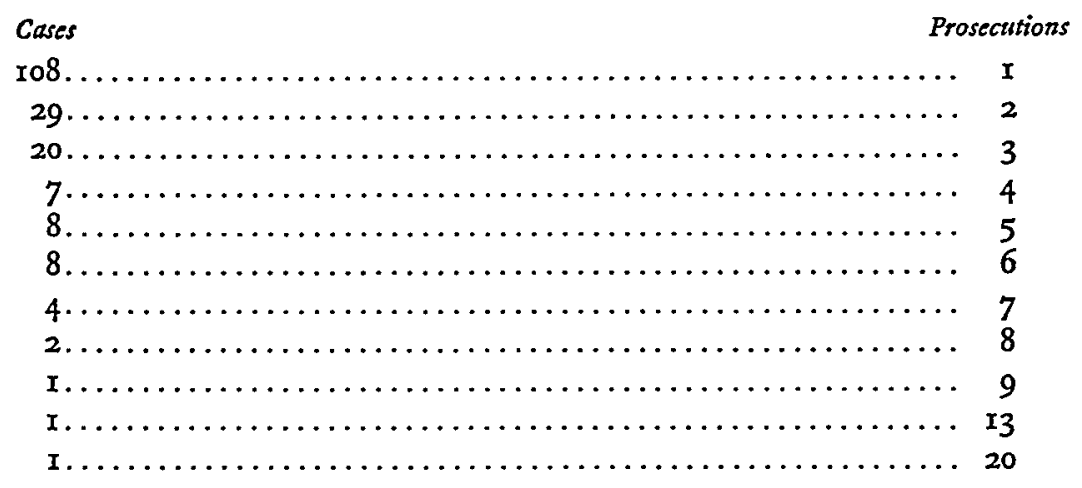

Upon hearing these cases, the court, depending on the degree of contempt shown, may enter an order placing the respondent on probation, may require him to pay a certain sum of money or stand committed, or may dismiss the case.

The controlling factor in alimony cases is wage income of husband. The most satisfactory evidence is presentation of employer's wage records. There should be no difficulty with the employer in obtaining this voluntary information when the reasons are fully explained to him. His certification of the wage records at the time of hearing of the case in court is rarely disputed by the defendant. The employer who refuses to give any information may be summoned into court on a subpoena duces tecum. This involves annoyance and loss of time and knowledge that such action can be taken may be the means of obtaining the information sought without appearance in court.

The claim by the husband that he is unemployed and without means to pay is not always a bar to obtaining some money for the dependents. In states having unemployment compensation (Michigan, for example, pays $\$ 16.00$ a week for I6 weeks) a sufficient showing may be made of capacity to comply with the alimony order in whole or in part. We believe it can be successfully argued that it was within the contemplation of the creators of this relief that the workman's dependents should share in its benefits.

In the Third Judicial Circuit comprising Wayne County, Michigan, there are eighteen circuit judges to whom in rotation are assigned alimony motions, orders to show cause and divorce hearings. Interlocutory orders and decrees are entered. By court rule the judge who entered the order retains jurisdiction and must hear all proceedings to enforce the terms thereof. This procedure gives the judge a better 
understanding of the problems involved and with the assistance and information given by a court officer, he can more satisfactorily dispose of controversial matters.

In the enforcement of alimony orders and decrees by contempt proceedings, personal service of a copy of the order and petition is mandatory. The respondent may be temporarily absent from home or, due to the nature of his employment, he may be difficult to serve. In our circuit we found that the process server was losing a lot of time making one or more trips to serve the papers. We believed that most of the men were not deliberately avoiding service, but due to certain circumstancs could not easily be found. We tried the plan of mailing the papers to the last known address. In 1938 we instituted 1,433 contempt proceedings, serving by mail. In 95 per cent of the cases the respondent personally appeared in court to answer the order to show cause. In the cases of non-appearance, the petition and order to show cause are dismissed for want of service. We then determine whether to apply for a writ of attachment or order to show cause and obtain personal service.

In 47 of the 48 states and the District of Columbia the courts have the statutory power to grant divorce decrees, either a mensa et thoro or a vinculo. The problem under discussion of enforcing alimony decrees in divorce cases is general. Undoubtedly, different ideas and systems prevail. Probably one of the most common factors involved is the inability of alimony payers to adhere rigidly to the cost of living within a definite or limited income. Rare is the man who claims he has no creditors. It is easy to say that the rights of the wives and children are paramount to creditors, but that will not stop a creditor from commencing suit and garnisheeing wages. There is an opportunity for judges and court officers to work out a plan of budget supervision. With the cooperation of the husband, a plan could be arranged whereby his pay check would be delivered to the court officer who would award a certain sum to the husband for necessary living expenses, a portion to the wife for the support of herself and children, and the balance allocated to creditors on a percentage basis. The creditors, even though they receive a small part of their bill, should not object provided payments are made with regularity.

I believe that the problems discussed in this article will be of more interest to the reader if there is included herein a few illustrative cases.

\section{Illustrattve Cases}

\section{I}

Facts: A decree of divorce was entered requiring the defendant husband to pay $\$ 8.00$ per week for the support of two minor children. A short time later, the man remarried and he now has three children by his second marriage. He is employed and his income averages $\$ 25.00$ per week.

The first wife insists that he obey the order of the court to pay for the support of the children of the first marriage. His second wife insists that her children are equally his responsibility and should have proper care. The husband pays a smaller amount than ordered, claiming it is impossible to pay more due to the fact he must pay rent, necessary household expenditures, clothing, etc. He states he is doing everything humanly possible 
and is unable to earn more money; that he realizes his obligation; that he has reached the limit of his physical and mental endurance and can carry on no longer and would welcome a jail term for contempt of court.

Discussion: The problem is one which embodies not only the legal enforcement of this order but also the social consequences of the enforcement. If this order is enforced to the full extent there is no doubt that his present home cannot be maintained and that the children of his second wife would suffer greatly for lack of the vital necessities of life. If the order is not enforced, then the two children of his former marriage will be denied the much needed financial assistance of their father. Which way shall the pendulum of justice swing? Either way, innocent little souls will suffer.

It is a simple matter to lose sight of the legal principles involved if the social aspect and consequences are considered. What is the solution of this grave and important question? It is possible that as civilization advances this problem will be ultimately decided, but, on the other hand, it may never be decided because man is mortal and subject to the frailties of human nature.

\section{II}

Facts: A decree of divorce was entered ordering the defendant husband to pay $\$ 25.00$ per week for the support of the plaintiff wife and minor child, aged sixteen, to continue until the child attained the age of eighteen years or upon the remarriage of the plaintiff wife.

The husband paid regularly until his suspicions were aroused that his wife had remarried. An investigation revealed no legal marriage and no cohabitation to establish a common-law marriage. However, the woman and the alleged husband had executed a mortgage to a company and the woman signed her name as his wife. The woman explains her action by stating that she was not married; had never lived or cohabited with this man, but intended to marry him in the future and signed the deed upon the insistence of this man who stated it would facilitate the issuance of the mortgage.

Discussion: The plaintiff wife seeks the enforcement of the alimony order. For the sake of argument it is agreed that no marriage of any kind was ever consummated and the only evidence is the mortgage bearing the woman's signature as the wife of another man. The solution of the question simmers down to the following conclusion: If she is not married, then she has perjured herself and committed a fraud upon the mortgage company. If she is married, the order is unenforceable. The legal entanglements into which this woman permitted herself to become involved can be discussed to no end, but enforcement of this order by the wife will give the husband an opportunity to prove that she has changed her social status.

\section{III}

Facts: At the time the decree was granted in this case, the man, Mr. X, had a good position with the $Y$ Corporation. There were no minor children involved, but an order for $\$ 12.00$ a week permanent alimony was entered. This alimony was paid each week regularly. Suddenly, about May x, I938, through an unexpected turn of affairs, this man found himself out of employment without fault on his part. The move being entirely unexpected, he had no opportunity to arrange his affairs and except for a few dollars in petty cash, he was without funds.

Mrs. $X$ discovered this when her check failed to arrive punctually and immediately made a complaint to our office. Mr. $X$ reported promptly, advising us of the circumstances, admitted his obligation to pay the full amount of $\$ 12.00$ per week, and promised to make up all arrearages as soon as he was able to get on his feet financially. In the mean- 
time he was attempting to do work on a commission basis and made a few small payments out of these earnings. This did not fit into Mrs. $X^{\prime} s$ concept of the situation. She had apparently been living on this income and making few attempts to adjust her finances so that she would be more or less independent. Regardless of circumstances, she felt that Mr. $X$ should be required to pay by the courts. She therefore filed a petition for an order to show cause.

Receiving this petition, Mr. $X$ realized the gravity of the situation. Upon being informed that Mrs. $X$ was entitled to her day in court, he obtained the services of an attorney. This attorney immediately took steps to modify the decree and reduce the alimony. When the contempt proceedings came on for hearing, the man was ordered to continue paying as he had, according to his ability, until the hearing on the modification of the decree. The final outcome was the reduction of the alimony order to $\$ 6.00$ per week and the man showed his sincerity by paying this sum regularly out of an income of only $\$ 16.00$ per week.

Discussion: If this woman had accepted the situation she would have had the same amount of money coming in with benefit of an arrearage being built up that would undoubtedly have been paid when the man's financial situation improved. Her unwise action in attempting to enforce the court order in an impossible situation, resulted in a substantial loss to herself.

\section{IV}

Facts: A decree of divorce provides that a man is to pay $\$ 4.00$ per week for the support of one minor child. He thereafter marries a woman with seven children. $\mathrm{He}$ is laid off at his place of employment and applies for welfare aid in the amount of $\$ 13.39$ per week for himself, wife and her seven children. Subsequently, the man is given a W. P. A. job and earns $\$ 13.84$ per week. His former wife has also remarried and insists that the man now pay as required by court order, claiming that her child comes before his stepchildren. He states he cannot pay as he owes certain bills to credit houses and for electricity, gas, etc., and also that he does not make enough to support his present family with all the necessities of life. He further states that if he is forced to pay, his present wife will leave him.

Discussion: This case presents essentially a social problem. When this man was obtaining welfare aid, he was not in contempt of court as he did not have capacity to pay. Now that he is employed, he earns approximately the same amount as was given him as welfare aid and yet he may now be in contempt. No doubt this W. P. A. job was given to him by the welfare agency so that it would not be required to assist him and his family. If he is required to pay for the support of his child as required by the decree of divorce, this will defeat the purpose for which he was given this job.

If he complied with the order, he would not have enough to support his present family and they would receive no help from the welfare agency as the man is employed. From this it appears that his compliance would cause the separation of the family. If the rights of the first child are given preference over those of the stepchildren, no more than a dollar or two a week could be obtained. 